\title{
Left atrial extension of metastatic renal cell carcinoma via pulmonary vein: A case
} report

\section{Metastatik renal hücreli karsinomun pulmoner ven yoluyla sol atriyuma uzanımı: Bir olgu sunumu}

\section{Mehmet Şeker ${ }^{1}$, Cengiz Erol ${ }^{1}$}

\begin{abstract}
Cardiac involvement from renal cell carcinoma is rare but well-recognized entity with several cases reported in literature. In majority of cases, the tumor reaches the right heart cavities through a neoplastic thrombus within inferior vena cava. Other mechanisms are dissemination via hematogeous spread and direct extension from either mediastinal or lung lesions involving pulmonary veins. Left heart involvement from renal cell carcinoma with normal inferior vena cava is extremely rare. Direct extension of metastatic pulmonary mass to left atrium from renal cell carcinoma via pulmonary veins is even rarer.

We report a case of left atrial extension via pulmonary vein from metastatic renal cell carcinoma who presented with left cerebellar and right thalamic acute ischemic lesions along with multiple metastatic lesions.
\end{abstract}

Keywords: Renal cell carcinoma, pulmonary vein, tumor embolus, left atrium.

Öz

Renal hücreli karsinomun kardiyak tutulumu nadir ancak iyi bilinen bir olgudur ve literatürde bir çok vaka bildirilmiştir. Tümör çoğu durumda, sağ kalp boşluklarına vena kava inferiyor içinde neoplastik trombüs yoluyla ulaşır. Bu mekanizma dışında, kardiyak tutulum, hematojen yolla olabileceği gibi, mediyastinal veya akciğer lezyonlarının pulmoner venler yoluyla direk yayılımı ile de ortaya çıkabilir. Ancak vena kava inferiyor tutulumu olmaksızın tümörün sol kalbe ulaşması son derece nadirdir. Renal hücreli karsinomun akciğer metastazlarının, pulmoner venler yoluyla sol atriyuma direk uzanımı daha da nadirdir.

Bu makalede, çok sayıda metastatik lezyonu olan ve sol serebellar ve sağ talamik akut iskemik lezyonlara bağlı belirtileri ortaya çıkan, pulmoner ven yoluyla sol atriyuma direk uzanımı olan metastatik renal hücreli karsinom olgusunu sunuyoruz.

Anahtar Kelimeler: Renal hücreli karsinom, pulmoner ven, tümör embolisi, sol atrium.

\begin{abstract}
${ }^{1}$ Department of Radiology, Faculty of Medicine, Istanbul Medipol University, Bağcılar, Istanbul/Turkey.
\end{abstract}

Informed Consent: The written consent was received from the patient who was presented in this study.

Hasta Onamı: Çalışmada sunulan hastadan yazılı onam alınmıștır.

Conflict of Interest: No conflict of interest was declared by the authors.

Çıkar Çatışması: Yazarlar çıkar çatışması bildirmemişlerdir.

Financial Disclosure: The authors declared that this case has received no financial support. Finansal Destek: Yazarlar bu olgu için finansal destek almadıklarını beyan etmişlerdir.

Geliș Tarihi / Received: 05.08.2018

Kabul Tarihi / Accepted: 04.09.2018

Yayın Tarihi / Published: 30.11.2018

Sorumlu yazar / Corresponding author Mehmet Seker

Adres/Address: Medipol University, Faculty of Medicine, Department of Radiology, Medipol Mega Hospital, No: 1, Bağcılar, 34214, Istanbul/Turkey.

e-mail: hikmet.irfan@hotmail.com

Tel/Phone: +90 5334533829

Copyright $($ ACEM 


\section{Introduction}

Left atrial extension of primary pulmonary tumors via pulmonary veins have been well documented and a number of such instances have been reported in the literature [1,2]. But, metastatic pulmonary tumors extending to the left atrium via the pulmonary veins are extremely rare $[3,4]$.

To our knowledge, the case we present here is the fourth citing left atrial extension via pulmonary vein from metastatic renal cell carcinoma (RCC) $[5,6]$. In this report, we will briefly review the epidemiologic and clinical features, imaging modalities and current therapeutic strategies.

\section{Case report}

A 37-year-old patient was admitted to our hospital for follow-up for RCC. He was diagnosed with RCC and had underwent left radical nephrectomy for limited stage RCC six years ago. After his first operation, he had undergone metastasectomy for right adrenal gland metastasis and then lobectomy for right lung metastasis. He was free of disease for five years.

For evaluation of the current status of the disease, positron emission tomography (PET-CT) revealed a large left lower lung mass and muscular metastasis and cranial magnetic resonance imaging (MRI) revealed multiple infratentorial and supratentorial metastatic lesions. Radiotherapy was added to his therapy for cranial metastasis.

After 4 months, he presented with numbness and left cerebellar and right thalamic acute ischemic lesions along with multiple metastatic lesions.

Echocardiography showed a mass in the left atrium that extends to the left inferior pulmonary vein (Figure 1). Although, the appearance was consisted with atrial thrombus, the presence of widespread RCC raised the suspicion of metastatic mass. In order to make differential diagnosis cardiac MRI and for probable cardiovascular surgery coronary computed tomography (CT) was performed. Coronary CT (Figure 2) and cardiac MRI (Figure 3) revealed a cavitary left lower lung mass showing contrast enhancement extending to the left atrium via the left inferior pulmonary vein. Cine MR images demonstrated that the mass protrudes towards the atrial outflow (Figure 4). Inferior vena cava (IVC) and the right heart chambers were normal.

Owing to multiple unresectable metastasis and high mortality and morbidity risks, cardiovascular surgery did not offer any intervention and the clinicians decided to continue therapy with a tyrosine kinase inhibitor (axitinib, Inlyta ${ }^{\circledR}$, Pfizer Pharmaceuticals) and to add anticoagulant agent.

Written consent was taken from the patient.

\section{Discussion}

Although cardiac involvement from RCC is rare, it is well-recognized entity with several cases reported in recent literature $[4,7,8]$. In majority of cases, the tumor reaches the right heart cavities through a neoplastic thrombus within IVC. RCC extends into the renal vein and IVC in about $5 \%$ to $15 \%$ patients and into the right atrium in about $1 \%$ of patients $[7,9$, 10]. Other mechanisms are dissemination via hematogeous spread and direct extension from either mediastinal or lung lesions involving pulmonary veins. But, cardiac involvement without IVC involvement is extremely rare [8]. In the literature, 31 cases with left heart involvement from RCC with normal IVC was reported [4]. Only 3 of these cases have left atrial involvement from RCC and these 3 metastasis spread hematogeneously. Extension of metastatic pulmonary mass from RCC via pulmonary veins is even rarer [5].

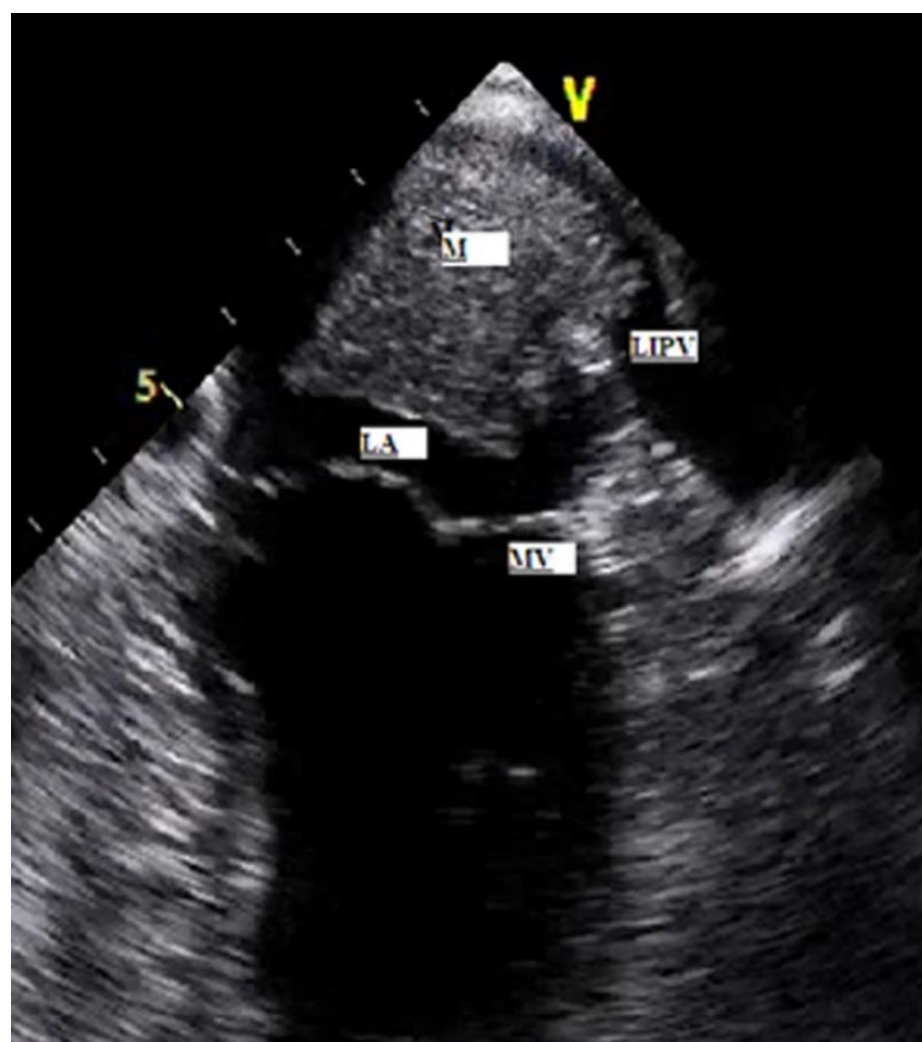

Figure 1. Transesophageal echocardiogram shows a mass (M) in the left atrium (LA) extending to the left inferior pulmonary vein (LIPV). Mitral valve (MV) is normal.

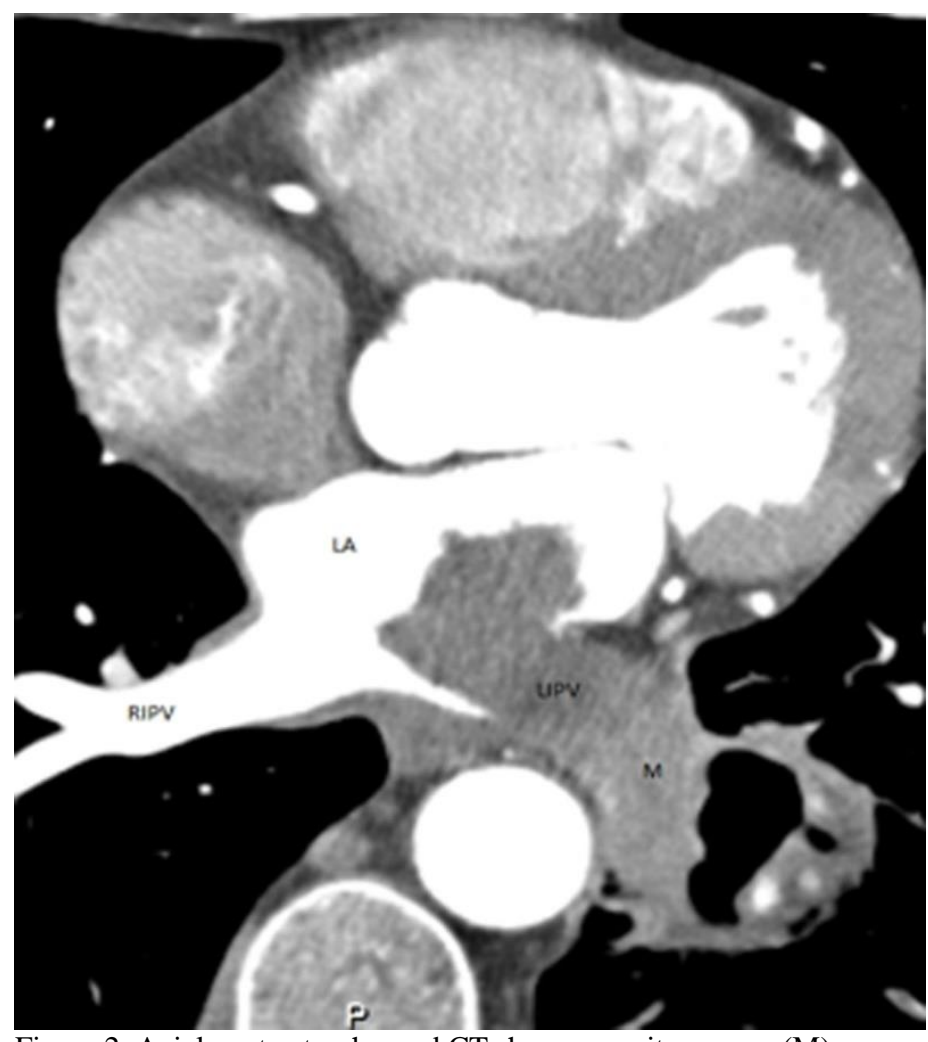

Figure 2. Axial contrast-enhanced CT shows a cavitary mass (M) involving the left lower lobe and extending into the left atrium (LA) through the left inferior pulmonary vein (LIPV). Right inferior pulmonary vein (RIPV) is normal. 


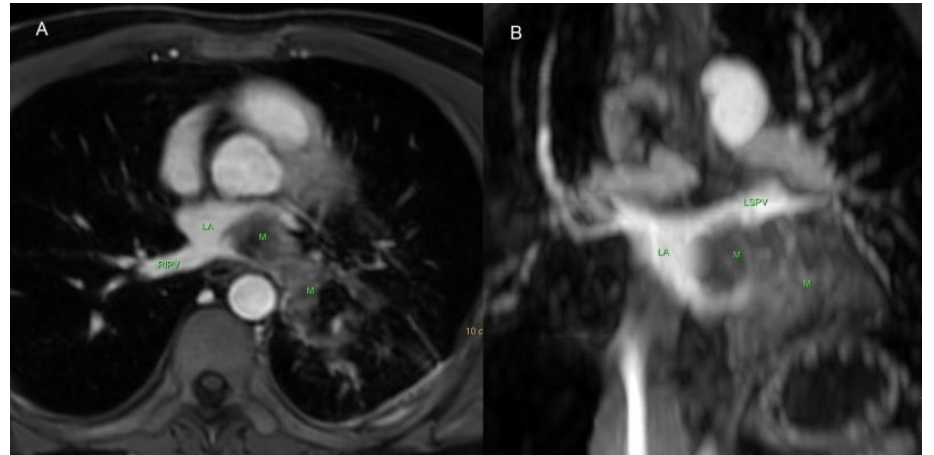

Figure 3. Axial (3a) and coronal-oblique (3b) contrast-enhanced fat saturated T1A demonstrates a contrast enhancing mass (M) in the left lower lobe extending to the left atrium (LA) via the left inferior pulmonary vein and normal right inferior pulmonary vein (RIPV) and left superior pulmonary vein (LSPV).

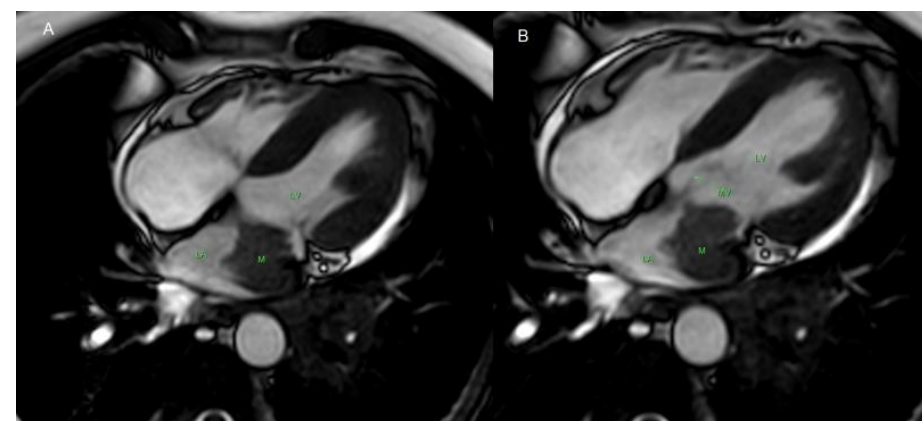

Figure 4. Axial BTFE (balanced turbo field echo) images during systole (4a) and diastole (4b) reveals a mass (M) in the left atrium (LA) protruding towards the mitral valve (MV). LV: Left ventricle.

Most cardiac metastases are clinically silent and may also present with dramatic manifestations that depend on their location and tumor size. Intra-cavitary metastases can cause right and left ventricular or atrial outflow tract obstruction and patients may represent with cardio embolic complications including stroke from left-sided cardiac metastasis or pulmonary emboli from right-sided cardiac metastasis.

Traditionally echocardiography is used as the first-line diagnostic test when there is a doubt for a cardiac mass. But, tissue characterization by means of echocardiography is limited [11].

The technologic advances in CT and MRI have resulted in improvements in imaging of cardiac structures and now, they are widely used as a diagnostic modality to assess cardiac masses. These modalities offer information about morphologic characteristics (location, size, infiltrative nature, presence of pleural/pericardial effusions) and vascularity of the mass with contrast enhancement which can be used to predict the malignancy probability of a cardiac mass $[11,12,13]$.

In recognition of its diagnostic capabilities, cardiac MRI is now widely used as a primary imaging technique in the workup of cardiac tumors [11]. CT offers an alternative second-line imaging strategy where cardiac MRI is not available or is contraindicated and when echocardiography alone has not been sufficient to fully assess a mass.

Most patients who develop cardiac metastasis already have disseminated extra cardiac involvement by the time of diagnosis and recognition of the process is usually not a problem. But, diagnosis may be problematic when the cardiac involvement is isolated. The primer differential diagnosis is thrombus. In such situations, cardiac MRI is indicated to differentiate between a cardiac tumor and an intra-cardiac thrombus. At MRI, the signal intensity of a thrombus can vary with the age of the thrombus. A fresh thrombus will have increased signal intensity on both T1- and T2-weighted images and older thrombus will be hypointense on both T1- and T2-weighted images. Infusion of gadolinium-based contrast material will also allow differentiation between tumors and intracavitary thrombus. Although, making this distinction may prove more difficult in the presence of an old thrombus [12].

Metastasis is a strong predictor in patients with RCC like other malignancies and cardiac metastasis poses therapeutic challenge. They are most often found in patients with multiple metastases and therefore, the most important goal of intervention is palliation of symptoms and improve quality of life, and prolong survival.

In fact, for many patients, surgical resection is not a viable option as a result of tumor location or medical comorbidities. Surgical resection is generally reserved for isolated cardiac metastasis, for patients in whom complete resection is technically feasible and for cases in which prognosis is otherwise good.

Similarly, treating metastatic RCC with cytotoxic agents and hormones have no rewarding results. But, as the biology of RCC became gradually understood, new therapeutic agents (tyrosine kinase inhibitors, the monoclonal antibody, and mammalian target of rapamycin inhibitors) have been developed and offer much improved progression-free survival [8].

In conclusion, the possibility of cardiac metastasis should be considered in any patient with a malignancy who develops new cardiac symptoms. Cardiac CT and MRI can be used as diagnostic tools with confidence.

\section{References}

1. Schreffler SM, Paolo WF, Kloss BT. Spontaneous showering of tumor emboli in a patient with advanced primary lung cancer: a case report. Int J Emerg Med. 2012;5:27.

2. Lin $\mathrm{M}, \mathrm{Ku} \mathrm{S}, \mathrm{Wu} \mathrm{M}, \mathrm{Yu} \mathrm{CJ}$. Intracardiac extension of lung cancer via the pulmonary vein. Thorax. 2008;63:1122.

3. Funakoshi Y, Mukohara T, Kataoka T, Tomioka H, Chayahara N, Fujiwara Y, et al. Left atrial extension of metastatic lung tumor via pulmonary vein: report on the first case of Ewing sarcoma. Rare Tumors. 2010;2:53.

4. Kojiro O, Yasuyoshi M, Kensuke M, Matsuo T, Mochizuki Y, Sakai H Left atrial metastasis of renal cell carcinoma: a case report and review of the literature. BMC Res Notes. 2014; 7:520.

5. Frederic C, Agathe S, Marc R, Kuntze T, Czesla M, Walther T, et al. Intracardiac renal cell carcinoma metastasis. Eur J Cardiothorac Surg. 2008;34:697-9

6. Fogel R, Balady G.J, Klein M.D, Rajaii-Khorasani A. Metastatic Renal Cell Carcinoma An Unusual Cause of Syncope. Chest. 1990;98:481-2.

7. Aburto J, Bruckner BA, Blackmon SH, Beyer EA, Reardon MJ. Renal cell carcinoma, metastatic to the left ventricle. Tex Heart Inst J. 2009;36:48-9.

8. Zhang B, Malouf J, Young P, Kohli M, Dronca R. Cardiac metastasis in renal cell carcinoma without vena cava or atrial involvement: an unusual presentation of metastatic disease. Rare Tumors. 2013;5:29.

9. Atik FA, Navia JL, Krishnamurthi V, Singh G, Shiota T, Pitas G, et al. Solitary massive right ventricular metastasis of renal cell carcinoma without inferior vena cava or right atrium involvement. J Card Surg. 2006;21:304-6.

10. Hunsaker RP, Stone JR. Images in clinical medicine. Renal cell carcinoma extending into the vena cava and side of the heart. New Eng J Med. 2001;345:1676.

11. Motwani M, Kidambi A, Herzog BA, Uddin A, Greenwood JP, Plein S MR imaging of cardiac tumors and masses: a review of methods and clinical applications. Radiology. 2013;268:26-43.

12. Hoffmann U, Globits S, Schima W, Loewe C, Puig S, Oberhuber G, et al. Usefulness of magnetic resonance imaging of cardiac and paracardiac masses. Am J Cardiol. 2003;92:890-5.

13. Fussen S, De Boeck BW, Zellweger MJ, Bremerich J, Goetschalckx K, Zuber $\mathrm{M}$, et al. Cardiovascular magnetic resonance imaging for diagnosis and clinical management of suspected cardiac masses and tumours. Eur Heart J. 2011;32:1551-60. 